\title{
Using of Chrysoperla carnea (Stephens) Larvae as a Biological Control Agent
} against Phyllocnistis citrella Stainton.

El-Masselati, H. S. I. ${ }^{1}$; A. A. Hafez ${ }^{2}$; F. F. Shalaby ${ }^{2}$ and E. E. Nowar ${ }^{2}$

${ }^{1}$ Higher Inst. of Sci. and Tech., Al-Zhraa, Libya.

${ }^{2}$ Plant Protection Dept., Fac. Agric. Moshtohor, Benha Univ., Egypt.

Correspondent author e-mail:Elhossenynowar@fagr.bu.edu.eg

\section{ABSTRACT}

Experiments were carried out in the orchards farm of the Fac. of Agriculture at Moshtohor, Benha University, Egypt on navel orange (Citrus sinesnes)seedlings grafted on Citrus volckamerianatostudy the effect of releasing $2^{\text {nd }}$ instar larvae ofthe aphid lion (Chrysoperla carnea) on citrus leaf miner (Phyllocnistis citrella) infestation rate in nursery of citrus plants. The efficiency of $C h$. carnea as a bio-agent against the citrus leaf-miner was estimated.A net wooden cage was divided into 12 cages that measured $75 \times 75 \times 250 \mathrm{~cm}$. each, and covered tightly with screenedfine nylon from all sides. Three treatments were examined compared with control (Tr.1: one \& Tr.2: two and Tr.3: four $2^{\text {nd }}$ instar larvae of Ch. carnea/ seedling). Obtained data clarified that releasing Ch. carnea on citrus seedlings caused considerable reduction in both the whole mean number of infested leaves and whole mean percentage of infestation by $P$. citrella. Treatment 2 was the best in reducing the seasonal mean infestation rate by $P$. citrella in citrus nursery by $43.70 \%$ while, the treatment 3 gave the best results in decreasing the numbers of $P$. citrella mines, larvae, pupae and infested leaves by 50.86, 78.37, 72.47 and $52.68 \%$, respectively. The mentioned treatments caused reductions in the whole mean number of mines, larvae and pupae of $P$. citrellato be 7.14, 1.14 and 0.68 /seedling, respectively.

Keywords: Biological control, Chrysoperla carnea, Phyllocnistis citrella

\section{INTRODUCTION}

The citrus leaf miner (CLM), Phyllocnistis citrella (Lepidoptera:Gracillariidae)is considered as an Asian pest species on citrus plants (Heppner, 1993). Within few years, this pest has moved into citrus growing regions of the world with incredible widespread in many countries (Beattie, 1993). This pest was recorded as outbreak population in the most citrus orchards of Egypt in 1994 (Tawfik et al., 1996). The citrus leaf-miner causes wide damage in citrus orchards such as; leaf curling and the presence of serpentine mines that are distinctly seen on the lower leaf surfaces and also on the upper leaf surfaces when heavy infestations occurs. Citrus leaf-miner may cause a great damage to trees and the leaves become severely destroyed. It is therefore necessary to control thisserious pest (Garrido, 1994). Many control measures should be done for the control of this pest. Chemical control is the common method for controlling this pest but the efficacies of different insecticides are expected not to be high because larvae are protected in their mines and pupae in their pupal chambers. In addition, the repeated use of pesticides for control of this pest is very harmful because of its residues in trees and fruits and also its harmful effect on natural enemies and causing distance in the whole ecosystem. Shareef et al. (2016) reported that generalist predators in their feeding can reduce pest populations effectively (Wise, 1993 and Romeldi et al, 2012). Several predators of $P$. citrella have been reported.Among these Chrysoperla spp. are the majorcontributors for $P$. citrella predation (Chen et al., 1989).Thepresent study was carried out to control the citrus leaf minerby using nonchemical safe effective methods. Releasing of Chrysoperla carnealarvae on $P$. citrellathat infested citrus plants was evaluated as a biological control tool.

\section{MATERIALS AND METHODS}

Experiments were conducted at the citrus orchards of the Fac. of Agriculture, Moshtohor, Benha University, Egypt on seedlings of some citrus varieties. The study dealt with releasing the second instar larvae of Chrysoperla carnea for the biological control ofthe citrus leaf miner (CLM)Phyllocnisilis citrella Stainton.

1. Effect of releasing the aphid lion larvae on citrus leaf miner infestation rate in the citrus nursery as a biological control method.

60 Navel orange (C. sinesnes) seedlings grafted on Citrus volckameriana were used for studying the effect of releasing $2^{\text {nd }}$ instar larvae ofthe aphid lion (Chrysoperla carnea) on citrus leaf miner infestation in citrus plantsnursery. These citrus seedlings were put in net wooden cage divided into 12 cages with dimensions $75 \times 75 \times 250 \mathrm{~cm}$. each.Each cage was tightly covered with finely screened nylon from all directions. In each cage, 5 citrus seedlings were placed as a replicate. $2^{\text {nd }}$ instar larvae of Chrysoperla carneawere obtained from the aphid lion production unit at the Fac. of Agric., Cairo Univ. and released on the examined citrus seedlings at three different rates under randomized complete blockdesign (RCBD) with three replications /treatment (Shareefet al, 2016). The number of infested and healthy leaves, mines, larvae and pupae of $P$. citrella were counted before releasing $2^{\text {nd }}$ instar larvae of Ch. carnea and weekly counted after that during successive 11 weeks.

Seedlings were divided into 4 groups as shown in the following diagram according to that described by Smith and Hoy (1995)and Mafil and Ohbayashi(2010):

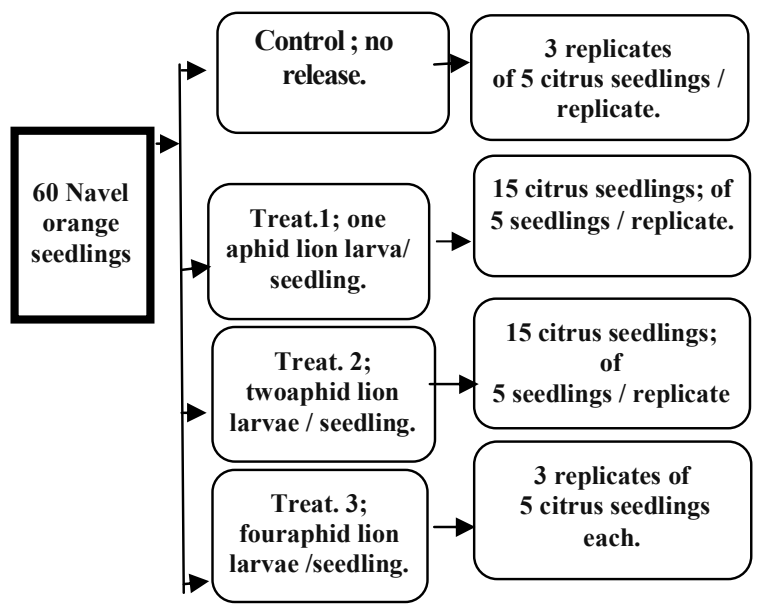


The number of infested and healthy leaves, mines, larvae and pupae of $P$. citrella were counted to calculate the infestation rate with citrus leaf miner.The infestation percentage was calculated according to the following formula:

$$
\text { Infestation rate }(\%)=\frac{\text { No. of infested leaves / sample }}{\text { Total No. of leaves / sample }} \times 100
$$

Experimental Design and Analysis:

All the data of experiments were analyzed in a randomized complete block design (RCBD) due to those obtained on the ANOVA tables by MSTAT-C version 1.41 according to Snedecor\& Cochran (1980). Also, significance between means was determinedby Duncan's multiple range tests at 0.05 probability level according to Steel \& Torrie (1980).
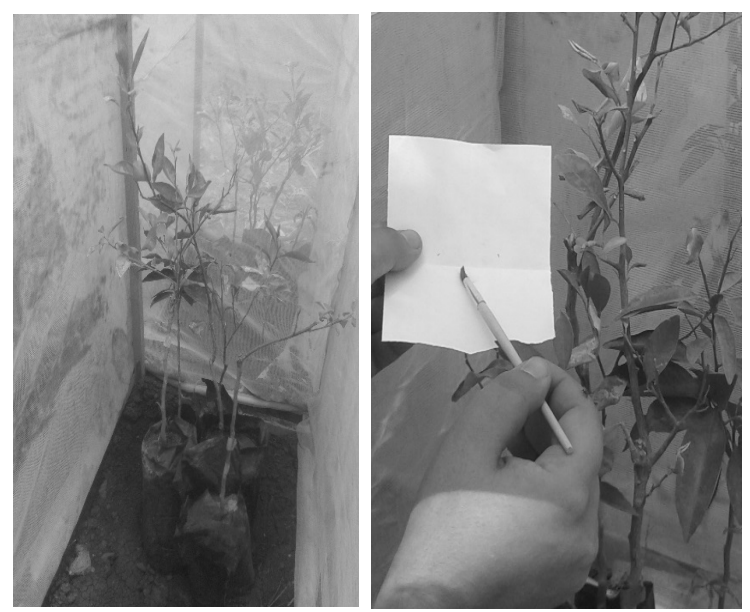

Unit of experimental cage . Releasing 2nd instar larvae 5 citrus plants represented of (Chrysoperla carnea) on one replicate. nursery

\section{RESULTS AND DISCUSSION}

1- Effect of releasing Chrysoperla carnealarvae on citrus leaf-miner infestation in citrus nursery plants during 2016.

Data presented in Table (1) indicate that the percentage of infestation by citrus leaf-miner, $P$. citrelladecreased by releasing the aphid lion $2^{\text {nd }}$ instar larvae. Data in this table proved that releasing two $2^{\text {nd }}$ instar Ch. carnea larvae per citrus seedling gave the highest reduction in the infestation rate with citrus leafminer by $-43.70 \%$ followed by releasing four $2^{\text {nd }}$ instar larvae $(-33.73 \%)$, while there was an increase in the infestation rate in the control treatment by $+14.30 \%$. These data were in harmony with Shareef et al (2016)who reported that using Ch.carneareduced the population infestation of citrus leaf miner by $14 \%$.In similar studies, Ahmed et al, (2013)observed slight reductions in citrus leaf miner infestation rates with time in Ch.carnea treatment, but the pest's population had non-significant differences in terms of increasingthe releasing rate and number of days after treatment.Parasitoid alone and in combination with others was found less effective in comparison with Ch.carnea on P. citrella populations (Amalin et al, 2002).

2- Effect of releasing Chrysoperla carnea larvae on reduction percentage of mines, larvae and pupaeof the citrus leaf miner on citrus plants in nursery during 2016.

As shown in Table (2) the highest reduction in mines caused by $P$. citrella $(-50.86 \%)$, was recorded in the treatment 3 , in which four 2 nd larvae of Ch. carnea were released on each citrus seedling, while the lowest reduction rate in mines number $(-37.70)$ was in treatment 1 (one Ch. carnea $2^{\text {nd }}$ instar larvae / seedling).On contrary, in control treatment there were no difference in larval counts from the beginning to the end of the experiment in the citrus leaf-miner mines rates.

Data also indicated that releasing four 2nd instar larvae of $C h$. carneaon each citrus seedling gave the highest reduction rate in citrus leaf-miner larvae by $78.37 \%$. On contrary, the lowest decreasing rate was obtained in control treatment by rate $-18.33 \%$.

As for the pupal counts, data in Table (2) revealedthat the treatment 3 (four $2^{\text {nd }}$ instar larvae of Ch. carneaper each citrus seedling) gave the highest reduction in leaf-miner pupal stage counts(-72.47\%), while the lowest decreasing rate was obtained in control treatment by mean rate $-20 \%$.

The present findings are supported by those ofUrbanejaet al. (2004)who reported that Ch.carnea could complete its development feeding on $P$. citrella only during the laboratory rearing. The same authors indicated that predation upon $P$. citrella had been satisfactorily correlated to flushing in Eastern Spain.

Table 1. Effect of releasing Chrysoperla carnea larvae at different rates on citrus leaf miner infestation rates on citrus nursery plants during 2016.

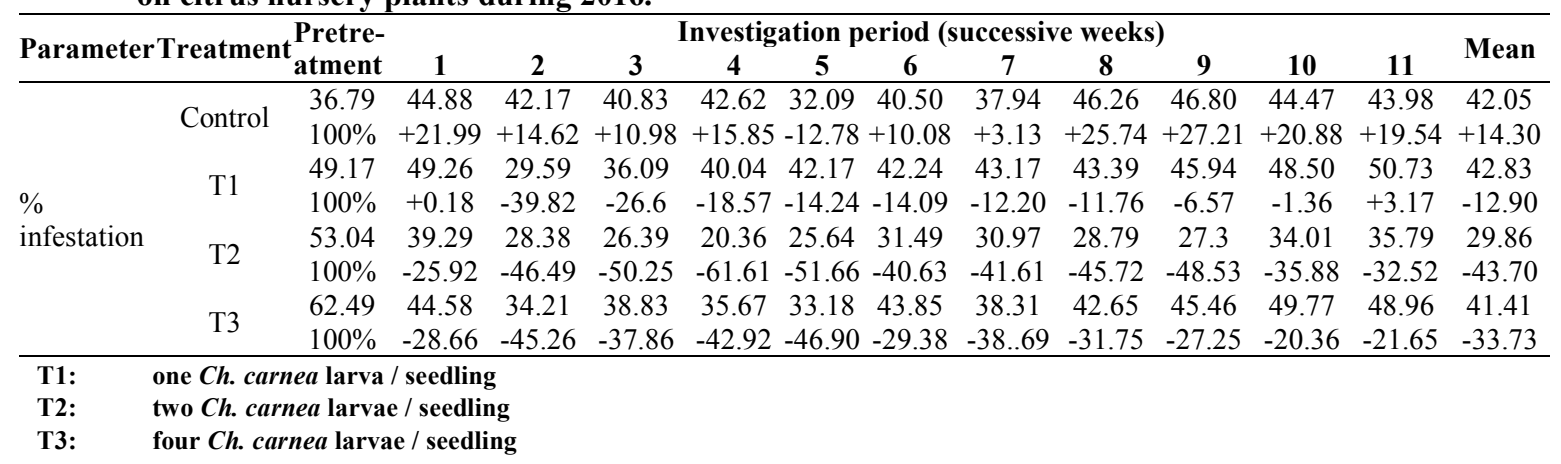


Table 2. Effect of releasing Chrysoperla carnea larvae on reduction percentage of mines, larval and pupal rates of citrus leaf miner on citrus nursery plants during 2016.

\begin{tabular}{|c|c|c|c|c|c|c|c|c|c|c|c|c|c|c|}
\hline \multirow{2}{*}{ Parameter } & \multirow{2}{*}{ Treatment } & \multirow{2}{*}{$\begin{array}{l}\text { Pretre- } \\
\text { atment }\end{array}$} & \multicolumn{11}{|c|}{ Reduction rates during investigation period (successive weeks) } & \multirow[b]{2}{*}{ Mean } \\
\hline & & & 1 & 2 & 3 & 4 & 5 & 6 & 7 & 8 & 9 & 10 & 11 & \\
\hline \multirow{8}{*}{ Mines } & \multirow{2}{*}{ Control } & 10.13 & 8.73 & 8.27 & 8.53 & 9.60 & 10.27 & 10.07 & 12.13 & 14.20 & 9.73 & 10.47 & 9.40 & 10.13 \\
\hline & & $100 \%$ & -13.82 & -18.23 & -15.79 & -5.23 & +1.38 & -0.59 & +19.74 & +40.18 & -3.95 & +3.36 & -7.21 & $0 \%$ \\
\hline & \multirow{2}{*}{$\mathrm{T} 1$} & 12.20 & 6.60 & 9.33 & 6.13 & 7.73 & 7.73 & 6.60 & 7.87 & 7.07 & 8.87 & 7.47 & 8.20 & 7.6 \\
\hline & & $100 \%$ & -45.90 & -23.52 & -49.75 & -36.64 & -36.46 & -45.90 & -35.49 & -42.05 & -27.30 & -38.77 & -32.79 & -37.70 \\
\hline & \multirow{2}{*}{$\mathrm{T} 2$} & 11.33 & 7.07 & 6.53 & 6.53 & 6.00 & 6.07 & 7.00 & 6.73 & 7.80 & 7.40 & 7.00 & 7.13 & 6.84 \\
\hline & & $100 \%$ & -37.60 & -42.37 & -42.37 & -47.04 & -46.43 & -38.22 & -40.60 & -31.16 & -34.69 & -38.22 & -37.07 & -39.63 \\
\hline & \multirow{2}{*}{ T3 } & 14.53 & 6.07 & 6.93 & 6.87 & 7.07 & 5.87 & 7.73 & 7.00 & 8.13 & 7.47 & 7.80 & 7.60 & 7.14 \\
\hline & & $100 \%$ & -58.22 & -52.31 & -52.72 & -51.34 & -59.60 & -46.8 & -51.82 & -44.05 & -48.60 & -46.32 & -47.70 & -50.86 \\
\hline \multirow{8}{*}{ Larvae } & \multirow{2}{*}{ Control } & 1.8 & 2.07 & 3.4 & 2.4 & 1 & 1.07 & 1 & 0.87 & 0.73 & 1 & 1.2 & 1.4 & 1.47 \\
\hline & & $100 \%$ & +15 & +88.89 & +33.33 & +44.44 & -40.56 & -44.44 & -51.67 & -59.44 & -44.44 & -33.33 & -22.22 & -18.33 \\
\hline & \multirow{2}{*}{$\mathrm{T} 1$} & 2.13 & 2.6 & 3.07 & 2.8 & 0.6 & 0.6 & 0 & 0.41 & 0.73 & 0.33 & 0.13 & 1.13 & 1.13 \\
\hline & & $100 \%$ & +22.07 & +44.13 & +31.46 & -71.83 & -71.83 & -100 & -80.75 & -65.73 & -84.51 & -93.90 & -46.95 & -46.95 \\
\hline & \multirow{2}{*}{$\mathrm{T} 2$} & & 3.2 & 3.33 & 2.67 & 0.6 & 0.87 & 0 & 0.6 & 1.13 & 0.67 & 0.67 & 0.73 & 1.13 \\
\hline & & $100 \%$ & +9.22 & +13.65 & -8.87 & -79.52 & -70.30 & -100 & -79.52 & -61.43 & -77.13 & -77.13 & -75.09 & -61.43 \\
\hline & \multirow{2}{*}{ T3 } & 5.2 & 2.93 & 2.67 & 2.6 & 0.73 & 0.4 & 0 & 0.4 & 0.8 & 0.4 & 0.8 & 0.8 & 1.14 \\
\hline & & $100 \%$ & -44.40 & -49.34 & -50.66 & -86.15 & -92.41 & -100 & -92.41 & -84.82 & -92.41 & -84.82 & -84.82 & -78.37 \\
\hline \multirow{8}{*}{ Pupae } & \multirow{2}{*}{ Control } & 1.4 & 1.33 & 2 & 1.33 & 0.4 & 0.53 & 1.1 & 1.13 & 1.4 & 0.9 & 1.03 & 1.22 & 1.12 \\
\hline & & $100 \%$ & -5 & +42.86 & -5 & -71.43 & -62.14 & -21.43 & -19.29 & 0 & -35.71 & -26.43 & -12.86 & -20 \\
\hline & \multirow{2}{*}{$\mathrm{T} 1$} & 1.8 & 1.53 & 2 & 1.67 & 0.27 & 0.27 & 0 & 0 & 0.47 & 0.2 & 0.13 & 0.07 & 0.6 \\
\hline & & $100 \%$ & -15 & +11.11 & -7.22 & -85 & -85 & -100 & -100 & -73.89 & -88.89 & -92.78 & -96.11 & -66.67 \\
\hline & \multirow{2}{*}{$\mathrm{T} 2$} & 2.13 & 1.93 & 2.07 & 1.33 & 0.2 & 0.4 & 0 & 0.47 & 0.73 & 0.47 & 0.47 & 0.47 & 0.78 \\
\hline & & $100 \%$ & -9.39 & -2.82 & -37.56 & -90.61 & -81.22 & -100 & -77.93 & -65.73 & -77.93 & -77.93 & -77.93 & -63.38 \\
\hline & \multirow{2}{*}{ T3 } & 2.47 & 1.67 & 1.53 & 1.47 & 0.27 & 0.13 & 0 & 0.27 & 0.53 & 0.27 & 0.67 & 0.67 & 0.68 \\
\hline & & $100 \%$ & -32.39 & -38.06 & -40.49 & -89.07 & -94.74 & -100 & -89.07 & -78.54 & -89.07 & -72.87 & -72.87 & -72.47 \\
\hline
\end{tabular}

\section{ACKNOWLEDGEMENT}

Thanks for all staff members of Plant Protection Department, Faculty of Agriculture at Moshtohor, Benha University for their help and encouragement.

\section{REFERENCES}

Ahmed, S., M.M. Shakir and A.Younis, 2013.Integrated management of Phyllocnistis citrella Stainton (Lepidoptera: Gracillariidae) through natural enemies, mineral oil and insecticide in a citrus nursery of Faisalabad, Punjab, Pakistan. Thai J. of Agri. Sci., 46(3): 135-140.

Amalin, D.M., J.E. Peña, R.E. Duncan, H.W. Browning and R. Mcsorley, 2002.Natural mortality factors acting on citrus leaf miner, Phyllocnistis citrella, in lime orchards in South Florida. Biocontrol, 4: 327- 347.

Beattie, G.A., 1993.Integrated control of the citrus (Hymenoptera: Trichogrammatidae) at low leaf miner. N. S. W. Agriculture, Rydalmere, N. S. W., temperatures. Pakistan Journal of Zoology, 42: 63-67. Australia CAB, IIBC.

Chen, R.T., Y.H. Chen and M.D. Huang, 1989. Biology of green lacewing, Chrysopa boninensis and its predation efficiency to citrus leafminer, Phyllocnistis citrella, pp. 96-105. In Studies on the Integrated Management of Citrus Insect Pests, Beijing, China Academic Book and Periodical Press.

Garrido, A., 1994.Phyllocnistis citrella Stainton, biological aspect and natural enemies found in Spain. In: Proceedings of the Meeting of the IOBC/WPRS Working Group on Integrated Control in Citrus FruitsCrops, Antibes, 27-28 Oct. 1994, IOBC/WPRS Bullet. 18(5): 1-14.
Heppner, J. B., 1993.Citrus leaf miner, Phyllocnistis citrella, in Florida (Lepidoptera: Gracillariidae: Phyllocnistinae). Trap. Lepid. (Gainesville), 4:49-64.

Mafi1, Sh. and N. Ohbayashi, 2010. Biology of Chrysocharis pentheus, an endoparasitoid wasp of the citrus leaf miner Phyllocnistis citrella Stainton. J. Agr. Sci. Tech., 12: 145-154.

Romeldi, F., M.I. Schneider and A.E. Ronco, 2012. Short and long-term effects of endosulfan, cypermethrin, spinosad, and methoxyfenozide on adults of Chrysoperlaexterna (Neuroptera: Chrysopidae). J. Econ. Entomol. 105: 19821987.

Shareef, M.F., A. M. Raza., K. S. Ahmed, M. A. Ali and M.Z. Majeed, 2016.Efficiency of Chrysoperla carnea and Trichogramma chilonisagainst infestation of citrus leaf miner (Phyllocnistis citrella Stainton). Academic J. of Ento., 9 (1): 14-19.

Smith, J. M. and M. A. Hoy, 1995.Rearing methods for Ageniaspis citricola (Hymenoptera: Eulophidae) released in a classical biological control program for citrus leaf miner Phyllocnistis citrella (Lepidoptera: Gracillariidae). Florida Entomol., 78: 600-608.

Snedecor G.W. and W. G. Cochran, 1980. Statistical Methods. The lowa state Univ., press Amer., USA, 7th.

Steel R.G. and J. H. Torrie, 1980. Principles and procedures of statistics A biometrical approach. 2nd ed., Mc Graw Hill book company, New York, USA. 


\section{El-Masselati, H. S. I. et al.}

Tawfik, M.F.S., M.S.I. El-Dakroury, I.A. Afifi, A.M. Ibrahim and F.M. Eid, 1996.Parasitic species secured from larvae and pupae of the citrus leaf miner, Phyllocnistis citrella Stainton (Gracillariidae:Lepidoptera) in Egypt. Egy. J. Bio. P. Cont., 6(1):111.

Urbaneja, A.,A. Muñoz1,A. Garrido, andJ. A. Jacas, 2004. Which role do lacewings and ants play as predators of the citrus leaf miner in Spain. Spanish J. of Agric. Res., 2 (3), 377-384.
Wise, D.H., 1993. Spiders in Ecological Webs. Cambridge University Press, Cambridge; New York.

\section{استخدام يرقات أسد المن كعامل من عوامل المكافحة البيولوجية لصانعة أنفاق أوراق الموالح.

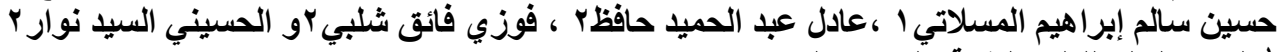

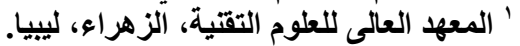 "قفم وقاية النبات، كلية الزراعة بمشتهر، جامعة بنها، مصر.}

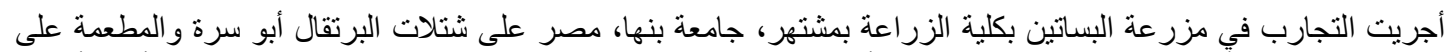

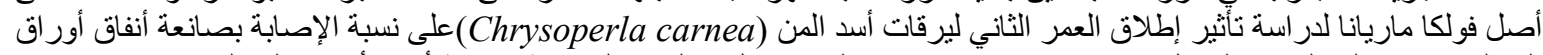

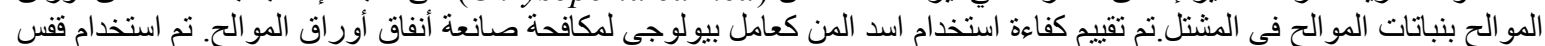

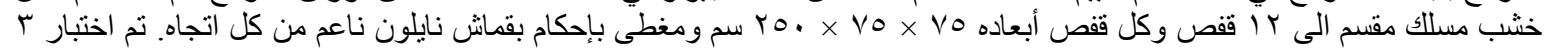

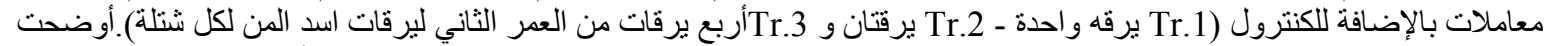

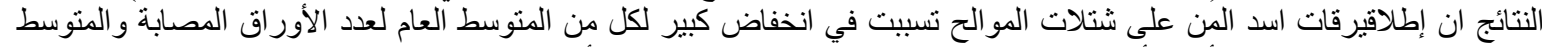

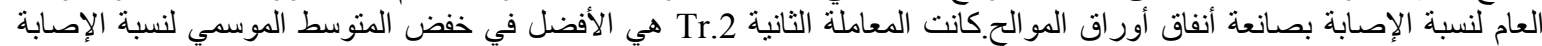

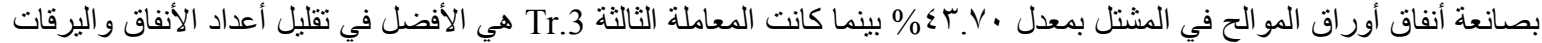

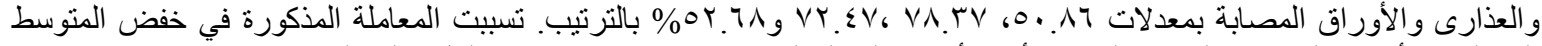

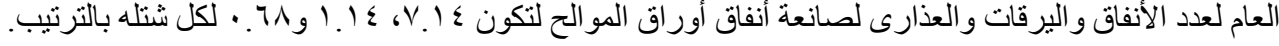

